\title{
NEOBJEVENÉ KNIHY. ČESKÁ NÁRODNÍ KNIHOVNA A ČÍTÁRNA V BELÉ CRKVI MEZI DVĚMA SVĚTOVÝMI VÁLKAMI*
}

Práce představuje meziválečné osudy krajanských Čechů v jugoslávské Bele Crkvi. Hodnotí jak a jakou měrou se čtenářství podílelo na udržení českého jazyka $\mathrm{v}$ tomto konkrétním případě české menšiny. Zdrojem výzkumu byly archiválie spolku - zápisy z porad a valných hromad a knižní katalogy. Kvalitativní analýzu zápisů doplnila kvantitativní analýza knihovního fondu z počátečních let České národní knihovny a čítárny v Bele Crkvi.

Klíčová slova: knihy, knihovna, čtenářství, Jugoslávie, Bela Crkva, národní identita.

The paper discusses the interwar fates of the Czechs in Yugoslav Bela Crkva. It evaluates, how great the role of reading was in preservation of the Czech language within this specific Czech minority. The source of the research was in the archives of the association - records of meetings and library catalogues. Qualitative analysis of records supplied a quantitative analysis of the library collection from the early years of the Czech National Library and Reading Room of Bela Crkva.

Keywords: books, library, reading, Yugoslavia, Bela Crkva, national identity.

„Podstatou národa je, aby všichni sdíleli mnohé a také aby všichni leccos zapomněli. "1

\section{Úvod}

V knize Představy společenství Benedict Anderson (2008: 22) upozorňuje na důležitost a funkci utváření si imaginárního obrazu o společnosti, se kterou se identifikujeme. Mluvíme-li o národu, hraje velkou roli naše imaginace. Národ je tedy po-

${ }^{*}$ Na vznik této publikace byla FHS UK poskytnuta Institucionální podpora na dlouhodobý koncepční rozvoj výzkumné organizace (MŠMT-2020).

${ }^{1}$ RENAN, Ernest. Co je to národ? In: HROCH, Miroslav (ed.). Pohledy na národ a nacionalismus. Čitanka textù. Praha: Sociologické nakladatelství, 2003, 27-28; Přeloženo z francouzského originálu Qu'est-ce qu'une nation? Takto nazvanou přednášku přednesl E. Renan 11. března 1882 na Sorbonně. Text přednášky byl publikován v týdenníku Francouzské vědecké společnosti (Association scientifique de France) 26. března 1882 a od té doby vyšel v řadě reedic $\mathrm{v}$ podobě samostatné brožury, jakož i v sebraných spisech E. Renana v nakladatelství Calmann-Lévy. Tuto Renanovu myšlenku si neodpustil uvést ani Benedict Anderson ve své knize představy společenství: „Podstatou národa je to, že všichni jednotlivci musí mít hodně společného a je rovněž nutné, aby toho všichni spoustu zapomněli. "Viz ANDERSON, Benedict. Představy společenství: úvahyo pưvodu a šírení nacionalismu. Praha: Karolinum, 2008, 22. 
litickým společenstvím, které je vybudováno na představách. O představy jde podle Andersona proto, že př́islušníci žádného národa (ani toho nejmenšího) nikdy nepoznají většinu ostatních jeho př́slušníků (nikdy je nikde neuvidí ani nikdy neuslyší). A přesto panuje obecná představa o jejich vzájemné sounáležitosti. V duchu Renanova výroku výše je zapomínání součástí aktu zmiňovaných představ (Anderson 2008: 21-22). Jakou roli můžou v tomto představování si sehrát jazyk a četba?

\section{Česká národní knihovna a čítárna}

Roku 1922 založili čeští krajané v srbské části Banátu spolek s názvem Česká národní knihovna a čitárna v Bele Crkvi, v roce 1933 byl spolek přejmenován na Československou besedu a pod názvem Česká beseda zde existuje dodnes. Původní název napovídá, že založení knihovny bylo důležitou, ne-li stěžejní aktivitou. Slovo národní je z našeho pohledu zkresleně vnímáno, dodnes jej místní užívají ve smyslu slova národnostní. Podařilo se jugoslávským Čechům aktivizovat české čtenáře? Napomáhaly aktérům knihy k resuscitaci pozapomenutého češství? Původní knihovní fond nebyl z počátku nikterak velký, ale rozrostl se až do dnešní unikátní podoby. Př́růstky do knihovny pocházely zejména z řad institucí bývalé Jugoslávie a Československé republiky i od jednotlivých dárců. V roce 1936 obsahovala knihovna celkem 435 knih (Matušek 1994: 125). Knihovna s knihami označenými kulatými razítky s textem Národní knihovna a čitárna nebo Československá beseda Bela Crkva byla později obohacena především knižním darem Československé obce v Bělehradě (cca 2500 svazků). Ta v sobě postupně soustřed’ovala i fondy zaniklých českých bělehradských spolků (např́klad Lumír, Československá jednota řemeslnická apod.). Po přerušení činnosti Československé obce v Bělehradě ve druhé polovině 60. let byly knihy, včetně masivních dřevěných skříní, které jsou ve spolku užívány dodnes, převezeny právě do Bele Crkve. Podle výpovědí místních Čechů vše proběhlo ve dvou fázích. Proces nabývání knihovny byl tedy nekontrolovatelný a živelný, proto docházelo hned $\mathrm{k}$ několika na sobě nezávislým pokusům o katalogizaci, počínaje od prvního knižního inventáře z roku 1922 (Kn. 14). Jeden z posledních pokusů proběhl v roce 2000, kdy Václav Štěpánek, který tehdy působil jako lektor českého jazyka na Filologické fakultě v Bělehradě, knihy rozdělil do věcných skupin a na hřbetech je opatřil štítky se signaturami a do několika sešitů pak začal zapisovat katalogizační záznamy. Podařilo se mu takto zpracovat pouze asi dvě třetiny fondu. Knihovna pak byla opět přesouvána kvůli rekonstrukci prostor a logika uspořádání tak byla narušena. Definitivní katalog byl uskutečněn až v rámci projektu Ministerstva zahraničních věcí ČR, který byl realizován ve dnech 16 . až 22. srpna 2010 a 1 . až 10. července 2011 za účasti studentů šesti univerzit v Srbsku a České republice. Mezi zapojenými byli též studenti bohemistiky z Bělehradu pocházející z řad české menšiny v Banátu. Údaje byly zpracovány v programu Excel podle předem stanovených kritérií: jméno autora, název knihy, místo a rok vydání, všechny provenienční a darovací přípisky, razítka a starší signatury. Záznamy posléze prošly korekturami a porovnáním se Souborným katalogem, který je volně dostupný na webových stránkách Národní knihovny v Praze (Linda 2008: 39-46, 2016: 1). 


\section{Nález a osud archiválií}

Během zmiňovaného projektu katalogizace knihovny byla rovněž nalezena řada archivních dokumentů. Cást archiválií se nacházela v trezoru, který byl komisionálně otevřen. Otevření trezoru bylo zaznamenáno zápisem ze dne 20. srpna roku 2010. Podepsáni vedle řešitele projektu Štefan Klepáček a Jozef Mareš, tehdejší předsedové Matice české a České besedy v Bele Crkvi. Další archiválie (podle Lindy často $\mathrm{v}$ dezolátním stavu) byly roztroušeny $\mathrm{v}$ regálech mezi knihami, ve sklepě nebo na půdě. Nezjištěným způsobem se dokonce některé z nich ocitly v České republice, ale byly objeveny a vráceny zpět do archivu; šlo o dvě rukopisné knihy se zápisy schůzí z období let 1933 až 1947. Neuspořádané archiválie tehdy se souhlasem funkcionářu České besedy Jaromír Linda převezl do Bělehradu k systematickému zpracování. Uspořádaný archiv pak byl vrácen zpět spolu s nově vypracovaným inventářem roku 2016 (Linda 2016: 1).

\section{Dnešní stav knihovny}

Knihovna prošla poměrně nepřehledným vývojem, s výjimkou citované studie Jaromíra Lindy (Linda 2008) se však nikdo doposud tímto materiálem nezaobíral. Fascinující na tom je, že se jedná o unikátní svědectví o české kultuře dvacátých a dalších let 20. století a o jejím zahraničním separátním vývoji. Současný stav knihovny i čtenářstva je zanedbaný, knihovna je v podstatě nepřetržitě zamčená a nikdo ji nevyužívá, Češi v Srbsku bud' nevědí, že existuje, nebo česky vůbec nečtou. A pokud ano, evidentně nestojí o tituly staré bezmála sto a více let. Tomuto nezájmu nedokázal zamezit ani projekt katalogizace a šiřrení informací spolu se zpř́stupněním knižního katalogu. Podle posledních zpráv byla knihovna převedena pod Českou národnostní radu v Srbsku a nejvzácnější knihy byly umístěny ve vitrínách v zasedací místnosti tohoto orgánu.

Průběh zmíněné katalogizace ke všemu vyvrátil původní předpoklad, že by knihovna mohla obsahovat i knihy nebo časopisy vzniklé činností českých (nebo česko-srbských, popríípadě jugoslávských) spolků, které na území dnešního Srbska v minulosti působily. Fond knihovny nicméně podle Lindy obsahuje celou řadu unikátních knih. Linda konkrétně vyjmenovává Spisů básnických knihy šestery Františka Ladislava Čelakovského z roku 1847 (sign. A/II - 9), Spisy Jan Husa z roku 1904 v originální vazbě významného českého umělce Františka Bílka (sign. C/III - 52-56) nebo sbírku básní Vladimíra Holana Blouznivý vějiřr z roku 1926, včetně jeho podpisu (sign. A/1 - 14). Jako nejstarší Linda určil knihu Bibli svatá z roku 1826 (sign. F/I - 63), (Linda 2011: VI).

\section{Meziválečné roky}

Z let 1922 až 1941 se zachovaly zápisy celkem 23 valných hromad (20 řádných a 3 mimořádných) a 94 spolkových schůzí (88 řádných a 6 mimořádných porad dozorčího a správního výboru) (Kn. 1; Kn. 2; Kn. 3). Předpokládáme ale, že se spolkových porad konalo mnohem víc. Zapisovatelé však v těchto př́ípadech bud' zápis vůbec nepořídili, nebo nedošlo k jeho přenesení do oficiální spolkové knihy. Naznačují to bud' zmínky o jistých zápisech, které bylo třeba před samotným jednáním na následujících poradách schválit nebo např́klad sumární počet řádných schůzí za uply- 
nulý rok uvedený na valných hromadách, který se však neshoduje s reálnými zápisy nalezenými v archivu spolku. I když se tedy nejedná o úplný záznam o spolkových aktivitách, valné hromady a mimořádné schůze jsou zajímavým a poměrně uceleným svědectvím o České národní knihovně a čitárně a později o Československé besedě v Bele Crkvi. Tyto zápisy nás provázejí malými i velkými dějinami a ukazují, jak historické milníky prožívali čeští jedinci vně hranic domovského státu. Na pořad dne se tak dostává i např́íklad téma hospodářské krize, jejímž následkem ,,spolek nemohl vyvinout větší činnost “. Spolek finančně značně vysilovala kapela, kterou si vydržoval, zpráva doslova hovoří o vyčerpání všech př́ijmů. Dokonce kvůli výlohám ani nemohla být ani uspořádána velká zábava, která tradičně přinášela do rozpočtu největší částky. Mnoho členů navíc nezaplatilo či neplatilo členské příspěvky (Kn. 1: 183185). Velmi emotivně krajané reagovali na atentát v Marseille, kde byl v říjnu roku 1934 zavražděn král Alexandr I. Karađorđević. Čeští krajané kromě stříbrného věnce za 100 dinárů věnovali zesnulému panovníkovi několikastránkový zápis do spolkové knihy (Kn. 2: 37-39).

\section{Knižní katalog}

K tomu, aby bylo možné původní fond spolkové knihovny podrobit jakékoliv analýze, bylo nutné nejprve jednotlivé záznamy převést do databáze. Originální rukopisný katalog (přesněji Inventář knih Národní Knihovny a Čitárny v Bele Crkvi od roku 1922, viz Kn. 14) obsahuje kolonky běžné čislo, jmeno spisovatele, název kníhy, ve svazcích (tj. počet svazků), ve vazbě (tedy typ vazby, která je dále rozlišována jako měkká a tvrdá), koupí čili darem (tj. způsob nabytí) a jako poslední poznámka (ve které zřejmě dodatečně byl zaznamenáván počet svazků u vícesvazkových titulů, nebo počet výpůjček). Protože ale při přepisech můžeme narazit bud' na nečitelnosti, nebo na nepřesnosti, bylo třeba nejprve titul za titulem podrobit srovnání s online katalogem Národní knihovny, který v tomto př́ípadě posloužil jako autoritativní opora při prohledávání česky vydávaných titulů. Vše bylo také překontrolováno se současným katalogem České besedy, kde se však vyskytuje nepoměrně více svazků (a velké procento původních knih je navíc ztraceno - takže se v současném katalogu všechny původní záznamy nevyskytují). Při zběžném procházení a kontrole zápisů v katalogu je možné postřehnout moment, kdy se různorodě zapisované tituly začnou objevovat se snahou o abecední pořádek. Od tohoto momentu lze pracovat s předpokladem, že zbytek katalogu byl zapsán při jediné katalogizační akci a že knihovna spolku byla otevřena a vybavena základním knižním fondem hned v době schvalování stanov a úplného počátku spolku.

\section{Analýza knižního fondu pưvodního katalogu}

Existující katalog bylo nutno doplnit o různá metadata. V momentě, kdy bylo možné zjistit konkrétní vydání, se informace rozrostly o další body. Celkový počet zkoumaných záznamů je 260, dle počtu zapsaných svazků se jedná o 277 exemplář̀̊. Zaměřil jsem se na největší fond, označený jako Literatura. Ve zmíněném rukopisném katalogu se vyskytují zvlášt' i další věcné skupiny, a to srbské knihy, dějepis, prírodověda, rưzné a hudebniny. Celkový počet svazkủ České národní knihovny a čítárny v Bele Crkvi v tomto inventáŕi byl 326 titulů ve 364 svazcích. 
Analýza způsobu nabytí zakládajícího fondu ukázala, že ačkoli celých 15 procent záznamů u sebe nemá ani vyplněnou nákupní částku ani jméno subjektu, který knihu daroval, je prakticky hlavním zdrojem př́růstků knihovny s 84 \% československé Ministerstvo školství a národní osvěty (zkráceně MŠANO). Za těmito dary stály pravděpodobně státem založené spolky, jako byl např. Svaz osvětový v Praze. Pokud přihlédneme $\mathrm{k}$ současnému stavu knihovny podle novodobého inventáře, je podle darovacích prríspěvků ve fondu 15 knih získaných darem MŠANO a 23 darem právě Svazu osvětového v Praze. Fakt, že více než tř̌i čtvrtiny počátečního fondu České národní knihovny a číárny v Bele Crkvi byly pokryty českou původní literaturou, nikterak výrazně nepřekvapí. Všechny zkoumané knihy byly vydané v českém jazyce a snaha o obnovu znalosti českého jazyka stála evidentně jako zakládající idea u zrodu tohoto krajanského spolku. Těžko soudit, zda tento poměr české literatury oproti zahraničním překladům odpovídá tehdejší nakladatelské praxi, či šlo o fond vybudovaný specificky nacionálně.

Mezi překladovými díly se na prvním místě objevují překlady z ruštiny, jen o procento za nimi jsou překlady z francouzského jazyka a na třetím místě se objevují překlady z angličtiny. Překvapit může fakt, že německý jazyk předstihne ještě polština. Obecně může tento přehled naznačit jistou rezervovanost viči německy píšícím autorům a překladům jejich děl. Jazyk bulharský nebo dánský jsou spolu s pěti procenty marginalitou. Otázkou je, jak vypadal český trh v desetiletích před námi zkoumaným rokem 1923. Zda se zde ocitáme před směrodatným výběrem českého knižního trhu, či nikoli. Bylo by třeba ještě v budoucnu porovnat, které jazyky se vyskytují ve vydáních z př́íslušných let, aby vznikl přehled o tom, jak se zastoupení jazyků překladů mění v závislosti na době svého vydání. Původní předpoklad, že panslovansky orientovaní krajané (respektive jejich funkcionáři) si budovali fond v českém jazyce tituly od českých či většinově slovanských autorů, se nepotvrdil. Čísla se zastavila u překladových titulů na $43 \%$ pro slovanské a na $57 \%$ pro neslovanské jazyky. Pokud však přičteme slovanské jazyky k češtině, je kompletní zastoupení slovanských jazyků ve fondu nad hranicí $85 \%$.

Zaměříme-li se na literární formy, je námi zkoumaný fond knihovny jednoznačně prozaistický. Vzhledem $\mathrm{k}$ tomu, že jde o část knihovny, kterou sami její tvůrci označili za literární, překvapí nás $3 \%$ naučných monografií (po jednom procentu jsou to cestopisy, historiografické knihy a biografie). Absolutní upozadění poezie může bud' naznačovat jistý záměr při budování fondu, nebo může jít o prostý odraz nabídky, která spolkovým knihovnám bývala poskytována ze strany Ministerstva školství a národní osvěty. Pokud se podíváme na složení fondu blíže z hlediska žánrového, dominují romány s povídkami (57 \% a $24 \%$ ), které jen okrajově doplňují novely ( $2 \%)$, následují různé sborníky a básnické sbírky, dramata pro účely divadelního kroužku a další v menšině zastoupené žánry, které však v součtu nepřesahují zastoupení $16 \%$. Blíže neurčitých knih je ve fondu pouhé jedno procento. Při přidělování žánrů jednotlivým svazkům jsem se přidržoval údaji v knize (respektive v katalogu Národní knihovny); zde bylo problematické zejména odlišení novel od románů, nechme pro jistotu tuto kategorii otevřenou dalším zkoumáním, protože předkládaný přehled může vykazovat jistou chybovost a lze jej brát jen jako orientační.

Počet ztrát se v našem př́padě vyčísluje velice těžko a s nepřesným výsledkem. Nemáme k dispozici žádná vstupní data, se kterými bychom mohli pracovat. Jediné, 
s čím operujeme, je že nejzazším rokem vydání př́ślušných titulů mohl být rok 1923, $\mathrm{k}$ čemu nás dovedlo složení fondu. $\mathrm{V}$ archiváliích se roky vydání nevyskytují a velice často se nevyskytují fyzicky ani v jednotlivých knihách. Po srovnání s katalogem současným můžeme dospět ale $\mathrm{k}$ tomu, že určíme definitivně tituly, které byly se stoprocentní přesností definitivně ztraceny. Proto je třeba operovat s faktem, že se jedná o minimální hodnotu prokázaných ztrát. Ta se pohybuje nad hranicí 14 \%. Pravděpodobně jde ale o poměrně větší číslo. Svazky ze současného fondu České besedy mohou totiž pocházet z jiných zdrojů, než je prvotní katalog spolku. Do fondu přibylo během let fungování spolku mnoho svazků z mnoha jiných spolkových knihoven či z řad jednotlivých dárců.

Jelikož původní katalog s 260 záznamy neobsahuje kolonku vydání, bylo třeba začít př́íslušné roky vydání dohledávat. Pokud se v katalogu České besedy objevil stejný titul s rokem vydání starším než z roku 1923, použil jsem dané vydání i pro tuto analýzu. Někdy bylo dohledávání snazší (např́íklad pokud byla kniha vydána pouze v jednom vydání), jindy bylo rok vydání nemožné dohledat. Je třeba brát tyto hodnoty s rezervou, neporovnával jsem fyzicky všechny knihy v současném fondu. V současném katalogu, pokud to nebylo možné zjistit prř́mo z provenienčních údajů, navíc pochopitelně neexistuje přesný záznam o celém osudu knihy, odkud přišla, a jestli prošla vícero spolkovými knihovnami. Rok vydání původních titulů spolku tedy dokážeme určit pouze u přibližně poloviny fondu. U 121 titulů nebylo možné zjistit odpovídající rok vydání. O první vydání jde u 86 titulů, u 53 titulů se podařilo první vydání prokazatelně vyvrátit. Jde o poměrně zajímavé číslo. Třetina fondu je prokazatelně v prvním vydání. U 12 knih šlo o vydání ze druhé poloviny devatenáctého století, u 74 titulů jde o století dvacáté. I tento ukazatel tedy svědčí pro to, že do spolkové knihovny přicházely častěji novinky než časem prověřené knihy.

Zajímavé je procentuální zastoupení knih, u kterých první vydání v českém jazyce pochází ještě z devatenáctého století. Jak následující charakteristiky upřesní, zastoupení jednotlivých roků vydání se neustále zvyšovalo. Přesto pochází z devatenáctého století úctyhodných $33 \%$ titulů. Tituly vydané ve dvacátém století pak s $61 \%$ pokrývají zajímavou část fondu, u zbylých $6 \%$ se datace nepodařila určit. Knihou z představovaného fondu, která byla na českém území vydána nejdříve, je Kenilworth Waltera Scotta, která česky poprvé vyšla v roce 1827. Druhým nejstarším titulem je Kapitánova dcerka Aleksandra Sergejeviče Puškina, která vyšla česky poprvé v roce 1847. Třetím pak Pohorská vesnice Boženy Němcové, ta vyšla vůbec poprvé roku 1856. Bohužel ani u jednoho titulu z fondu nedokážeme určit, o která konkrétní vydání v našem př́ípadě šlo. Je jasné, že hlad po novinkách byl velký. Pokud bychom přijali pro vytvoření přehledu aritmetický průměr vydaných knih na jediný rok (vzhledem k tomu, že ze dvacátých let můžeme počítat pouze tři roky), byla by čísla následující: $\mathrm{v}$ devadesátých letech devatenáctého století by tento poměr vycházel 4,8 knihy na rok; v nultých letech dvacátého století 5,4; v desátých letech pak 6,6 a ve dvacátých letech 12,7 (!). Jde samozřejmě o orientační hodnotu, jejíž smysl snáze pochopíme za pomoci následujících srovnání. Zaměříme-li se pouze na množinu těch knih, u kterých je možné dohledat všechna data, dojdeme k zajímavým číslům. Zde už operujeme s přesnými daty vydání, tak jak se je podařilo zjistit dle komparace dat z katalogu Národní knihovny a současného katalogu České besedy. Pokud bychom sečetli zastoupení fondu od roku 1918 do roku 1923 (tedy co se roků vydání 
týká za posledních pět až šesti let), zjistili bychom, že tituly vydané v těchto letech pokryjí celkem $64 \%$ z fondu. Více jak 83 knih z 260 tedy bylo vydáno v posledních pěti, šesti (!) letech. Zatímco od roku vydání 1876 se v podstatě až do počátku dvacátého století jednalo o ojedinělé tituly, k opravdovému zlomu dochází až v zmiňovaném roce 1918, respektive 1919, kdy najednou pozorujeme nárůst titulů na 18 . Roku 1920 odpovídá taktéž 18 vydaných titulů, roku 1921 ještě o jeden více - a roku 1922 dokonce 25 titulů. Rok 1923 je pak zastoupen třemi výtisky. Počet svazků vydaných $\mathrm{v}$ roce 1923 ukazuje v kontextu ostatních čísel, že ke katalogizaci muselo dojít někdy z počátku roku 1923, kdy ještě nebylo mezi dary více novinek z příslušného roku.

Celkový počet autorů, který lze zjistit z původního katalogu, je 139. U této kategorie lze porovnávat snadno ověřitelná data. Jde např́ílad o dobu, v níž žili. Pokud se autor narodil v osmnáctém století a zemřel ve století devatenáctém, spadá do kategorie 18/19. stoleti (4 \%). Analogicky je tak i se skupinami 19. stoleti (17\%) a 19/20. století ( $78 \% ; 1 \%$ jsou neznámí autoři). Zde je patrné, že se opět projevuje trend pořizovat do fondu novější autory. S patnácti tituly ve fondu je však nejčastěji zastoupeným autorem Karel Václav Rais, druhá v pořadí je Karolina Světlá se čtrnácti knihami, třináct titulů má ve fondu Alois Jirásek. Jeho knihy se však ve fondu vyskytují ve vícero exemplářích, celkem v počtu osmnácti svazkủ. Básnických sbírek je ve fondu pouze deset, jediný autor, který je zastoupen více tituly, je se dvěma svazky Antonín Sova (Vybouřené smutky a Lyrika lásky a života).

Zajímavým ukazatelem je i počet autorek. Největší zastoupení žen připadá na ročníky narozené v padesátých (čtyři autorky) a šedesátých letech (pět autorek). Počtem titulů suverénně vede Karolina Světlá celkem se 14 svazky, druhá je se šesti tituly Teréza Nováková a třetí s pěti knihami Božena Němcová. Dvě autorky pak publikovaly pod mužským pseudonymem. Anna Lauermannová-Mikschová jako Felix Téver a Amálie Vrbová jako Jiř́ Sumín. Jen těžko budeme odhadovat, jestli je zde přítomných 14 \% vyšším či menším číslem, než jaké se pohybovalo v českém literárním provozu do roku 1923.

\section{Diskuse}

Navzdory očekávání se v pramenech žádné zápisy o čtení neobjevují. Veškerý výzkum mohl být založen pouze na útržkovitých informacích o počtu čtenářu a knih. Teprve na valné hromadě roku 1928 padlo číslo 500 přečtených knih ročně, což samotné plénum překvapilo, takže došlo $\mathrm{k}$ usnesení, že je potřeba přesné evidence, která by měla navíc zamezit ztrátám. Nicméně přesná čísla bud' nepřicházela, nebo prostě nedošlo k jejich zanesení do zápisu. Zpráva z roku 1931 mluví už o 292 přečtených titulech. Další zmínky o přečtených knihách ještě menší počty, v roce 1933 se přečetlo $73 \mathrm{knih}$, o rok později 148, a další rok zase pouze 90 . v roce 1936 bylo přečteno 121 knih, dalšího roku 65 knih a v roce 1939137 knih. Roku 1936 navštívilo knihovnu pouze 22 čtenářu a roku 1937 dokonce jen 12, proto se spolek rozhodl vyměnit část fondu s besedou ve Fabiánu (Českém Sele).

Vlastní knihovna procházela poměrně krušnými začátky, kdy většina krajanů v Bele Crkvi nejevila o knihovnu s čítárnou zájem. Minimálně třináctkrát spolek vyměnil knihovníka, protože se jednalo o funkci volenou. K volbě docházelo každý rok podobně jako u jiných funkcí na valné hromadě. Netušíme, jestli šlo o funkci 
prestižní, či naopak o neoblíbenou službu, které se jednotliví knihovníci až na výjimky rok co rok zbavovali. Jmenovitě se jedná o tyto knihovníky: Josef Irovič, Václav Balát, Emil Mokráček, Václav Hubálek, J. Glazer, Josef Eliáš, Antonín Tichý, Josef Strnad, Josef Eliáš (minimálně tři roky po sobě, přesné informace chybí), Jan Irovič, František Rafáč, Václav Kvapil, Jan Irovič (dva roky po sobě) a Josef Irovič.

Postupný nárůst knižního fondu nelze přesně sledovat, protože údaje o počtu knih v knihovně se objevují nesystematicky - chybí prŕrůstkový seznam knih (přesněji spíše neexistuje), členové spolku ke katalogizaci přistoupili sice zodpovědně, avšak naprosto nepoučeně. Kulatými razítky s názvem spolku se knihy evidentně opatřovaly ex post, či spíše chaoticky, protože staré razítko se objevuje v zápisech schůzí i po změně názvu na Československou besedu, zatímco razítko s novým názvem se místy objevuje i v zápisech, kdy spolek ještě nesl původní jméno Česká národní knihovna a čitárna.

Vủbec je třeba brát dochované prameny s rezervou, protože zápisy nebyly vedeny (či se nezachovaly) ze všech porad. Je třeba se opírat zejména o informace z valných hromad, které byly do knihy většinou zřejmě také opisovány až zpětně. Stranou necháváme i fakt, jak přesně zápisy dokázaly kopírovat realitu a věrně zachycovat reálný průběh porad. V podstatě první obsáhlejší zpráva o spolku samotném se dochovala v zápisu valné hromady v roce 1925, kde zavládl lehký optimismus i přes sporadické využívání knihovny s čítárnou. První zmínka o přesném počtu členů se objevuje na valné hromadě z roku 1927. Ke konci roku 1926 měl spolek 60 členů, o dva roky později se vyskytuje zmínka o 71 členech. V roce 1930 se setkáváme s poznámkou předsedy Tomáše Iroviče, že místo aby počet členů stoupal, tak klesá. Mimořádné valné hromady 4. června 1933 se dokonce zúčastnilo pouze 11 členů.

Celkem solidní přehled máme o hospodaření spolku, které odráží úspěšné i neúspěšné roky nebo dokonce dopad hospodářské krize. V roce 1929 došlo k veliké investici do hudebních nástrojů pro spolkovou kapelu, šlo o celkem 5400 dinárů. Roku 1927 se také poprvé objevuje zmínka o fondu pro výstavbu nebo koupi Národního domu (spolek fungoval v pronajatých prostorách) a o eventuální české škole, která byla systematicky vyřešena následujícího roku, kdy do nově otevřeného českého oddělení nastoupilo 42 dětí. Po vyřešení školní otázky se pozornost plně upnula ke koupi spolkového domu, který se nakonec po veliké sbírce a dlouhodobém odklánění prostředků na př́slušný fond povedlo koupit za 50000 dinárů.

Největším přínosem výzkumu je samotné upozornění na doposud ne příliš probádanou oblast českých kulturních dějin a na roli literární kultury při obnově či zachování národní identity Čechů dnešního východního Srbska. Nabízí se do budoucna tyto výstupy komparovat s jinými fondy českých spolkových knihoven a přihlížet nejen $\mathrm{k}$ historickému vývoji českého etnika, ale zejména k aktuálnímu stavu - aby se potvrdila či vyvrátila myšlenka, že ačkoli byla už od dob obrození česká kultura budována jako lingvocentrická, lze si uchovat českou národní identitu i bez znalosti českého jazyka a bez čtení české literatury nebo literatury do českého jazyka přeložené.

Vše zmíněné vznáší řadu otázek. Nakolik etničtí Češi ovládali svůj mateřský jazyk? V zápisech se objevuje množství gramatických chyb, např́klad namísto grafému ,ch“ je často pod vlivem srbštiny zapisováno „h“. Čím byl způsoben jejich ne- 
zájem o četbu? Šlo o nevhodný výběr titulů, či v tom byl jiný důvod? Jakými čtenáři vlastně členové spolku byli, jak prožívali četbu a vnímali samotné knihy a proč? Proběhl reálně přerod češství na čechoslovakismus, nebo mělo přejmenování plnit funkci záštity spolku pouze po formální stránce? Úvahy o těchto aspektech otevírají pole pro další bádání.

\section{Závěr}

Komparací aktuálního inventáře s kinventýřem původním (doplněným o mnohé podrobnosti) jsme dospěli k datům, která bylo možno podrobit kvantitativní analýze. Hodnocena byla žánrovost či zastoupení literárních druhů, otázka překladů titulů (a o jaké jazyky originálů šlo), četnosti prvních vydání, způsob nabytí knih a další hlediska. Kvalitativně analyzované zápisy valných hromad byly porovnány s daty kvantitativní analýzy knižního fondu. V zápisech figurují často zmínky o potřebě vzděláváni se, povzneseni tělesném i duchovním v českém duchu, o nepolevováni ve snahách spolku (Kn. 1: 1-4), pravidelně se vyskytují zmínky o nepochopení snah o blaho zanedbané menšiny ze strany mnoha krajanů. Samotné čtenářství ale v zápisech téměř není tematizováno. $Z$ prvních let existence spolku chybí prakticky všechna data $\mathrm{z}$ knihovny - počet titulů, počet čtenářů a počet vypůjčených knih. První stopa hodnocení čtenářské situace je až z 1. března 1925, jde tedy o zápis vztahující se k roku 1924: „Celkem se může ř́ci, že naši krajané, jsa neuvědomělí, daleko ještě neuměji si využíti tento zdroj vzdělání; mohlo by se mnoho více čisti. Ale průměrně pokrok se [...] cítí. Nejráději čtou historické romány. “(Kn. 1: 70).

Čtenářství se v podstatě ve spolku za celou jeho existenci (připomínám název Národní knihovna a čítárna) jako priorita neprosadila. Do popředí se dostávají snahy o českou krajanskou školu (první zmínka je ze 3. července 1927), kterou se podaří zrealizovat ve školním roce 1928/1929 (Kn. 1: 113). Jinak jde spolku ale o záležitosti jiného rázu. Název Knihovna a čítárna se stal pouhou záštitou krajanského spolku, který zkoušel divadlo a držel kapelníka pro vlastní muzikanty, pořádal pravidelné hudby - je to možná i jeden z důvodů, proč se spolek v roce 1933 přejmenoval z České národni knihovny a čitárny na Československou besedu.

Analýzou knižního katalogu jsme dospěli ke zjištění, že minimálně první rok se ve spolkové knihovně vyskytovalo pouhých 23 českých knih. V roce 1923 (či později - přesné datum není v pramenech uvedeno) získala Česká knihovna a čitárna od Ministerstva školství a národní osvěty 237 titulů. Knihy jsou od tohoto momentu řazeny v katalogu abecedně (nabízí se předpoklad, že šlo o jednorázový dar). Pro rok 1923 hovoří jako svědectví data vydání knih. Spolek totiž disponoval i tituly, které byly vydány pouze jednou, a to v roce 1923. Je však možné, že k prvotní katalogizaci došlo jednorázově, a teprve po 23 zapsaných titulech přišla potřeba provádět zápisy abecedně. Důležité pro analýzu samotného katalogu knih je fakt, že výběr titulů byl ovlivněn ze strany donátorů (tedy zejména MŠANO). Při pohledu na seznam titulů je však nutné říci, že šlo o výběr velice zodpovědný.

Další př́ri̊̊stky do fondu byly různého charakteru, jak již bylo řečeno, většinou šlo o převod knih z fondů zaniklých krajanských knihoven v jiných městech Jugoslávie, (Linda 2011: III). Na základě způsobu nabytí prvních př́růstků nás tedy nemůže překvapit, že mezi knihami je minimálně 33 \% svazků zaručeně v prvním vydání (popří- 
padě $20 \%$ knih je zaručeně pozdějšího než prvního vydání). Z literárních forem dominuje s 88 \% próza, zbylé formy jsou v zastoupení maximálně po $4 \%$. Z celkového počtu 260 knih (všechny tituly v češtině) bylo 74,6 \% českých a $25 \%$ překladových (0,4 \% nelze určit). Existuje jednoznačná potřeba číst v českém jazyce, což samozřejmě nepřekvapí. Zda se jedná o české autory, je sice akcentováno, ale nejedná se o podmínku či prioritu. Zajímavým se zdá mezi překladovými tituly $43 \%$ zastoupení překladů ze slovanských jazyků (polština, ruština a bulharština). Pokud připočteme tento počet k českým originálům, převáží jazýček vah v zastoupení slovanských překladových literatur na hodnotu 85,4\%.

Více než pro českou myšlenku tento fakt svědčí pro myšlenku všeslovanské vzájemnosti, která je v Srbsku obecně stále živá a patrná napříč celou společností. Dá se říci, že se záměr zastavit ,jugoslavizaci“ Čechů nevyplnil, minimálně nebyl realizován mezi samotnými členy spolku (určitou nadějí mohly být děti navštěvující českou školu). Svědectvím může být porovnání dvou záznamů ze třicátých let. 9. října roku 1934 došlo v Marseille k atentátu na krále Alexandra I. Karađorđeviće. Zapisovatel reflektuje tuto událost na třech stranách textu (Kn. 2: 34), toto rozsáhlé oplakávání se nedá prakticky vůbec srovnávat s pětiřádkovou vsuvkou o smrti prezidenta Tomáše Garrigua Masaryka v roce 1937, (Kn. 3: 15). Čeští krajané v Bele Crkvi tedy na počátku deklarovali mizející češství, které chtěli resuscitovat na základě vzdělávání „v českém duchu“. Jako nástroj vzdělání zamýšleli opřít se o četbu a nazvali spolek Národní knihovnou a čítárnou. Pátá generace Čechů, která prošla germanizací a mad'arizací, po první světové válce narazila na logické posrbštování. Český lingvocentrismus však k rekonstruování češství a udržení českého jazyka nestačil. Obzvlášt', když vytížení knihovních služeb, jak jsme ukázali v této studii, nedostálo svého očekávání. České knihy v Bele Crkvi zůstávají a zdá se, že (minimálně pro čtenáře) zůstanou i nadále neobjevené.

\section{Literatura}

Anderson, Benedict. Představy společenství: úvahy o původu a šíření nacionalismu. Praha, Karolinum, 2008.

Hroch, Miroslav (ed.). Pohledy na národ a nacionalismus. Č́tanka texti̊. Praha: Sociologické nakladatelství, 2003.

Linda, Jaromír. Archiv České besedy Bela Crkva Inventár̆. 2016.

Linda, Jaromír. „O knihovně (nejen) České besedy v Belé Crkvi“. Opera Slavica XVIII, 3 (2008): 39-46.

Linda, Jaromír. Místní a autorský katalog knihovny České Besedy v Belé Crkvi. Bělehrad: Česká beseda Bela Crkva, 2011.

Matušek, Josef: Češi v Chorvatsku. Daruvar: Jednota, 1994.

Renan, Ernest. „Co je to národ?“. [In:] Miroslav Hroch (ed.) Pohledy na národ a nacionalismus. Čítanka textů. Praha: Sociologické nakladatelství, 2003: 24-35. 
Pavel Jonák

\title{
Použité prameny
}

Archivní prameny

Archiv České besedy v Bele Crkvi

(Kn. 1). Zápisy správního výboru Národní knihovny a čítárny Bela Crkva 1922-1933. Kniha č. 1.

(Kn. 2). Zápisník Československé besedy v Bele Crkvě 1933-1937. Kniha č. 2.

(Kn. 3). Zápisy správního výboru Československé besedy v Bele Crkvě 1937-1947. Kniha č. 3

(Kn. 14). Inventář knih Národní knihovny a čítárny v Bele Crkvě od roku 1922. Kniha č. 14 .

Павел Јонак

\author{
НЕОБЈАВЉЕНЕ КЮИГЕ. ЧЕШКА НАРОДНА БИБЛИОТЕКА \\ И ЧИТАОНИЦА У БЕЛОЈ ЦРКВИ ИЗМЕЪУ ДВА СВЕТСКА РАТА
}

\section{Резиме}

Упоређивањем актуелног каталога са оригиналним каталогом, добијени су подаци који су могли бити подвргнути квантитативној анализи. Било је неопходно усредсредити се на жанрове и заступљеност различитих књижевних врста, питање превода наслова (и који су језици оригинала били), учесталост првих издања, начин набавке књига и на друге аспекте. Квалитативно анализирани записници са пленарних седница упоређивани су са подацима из квантитативне анализе збирке књига. Ови записи често садрже напомене о потреби образовања, физичког и духовног уздизања у чешком духу, непоколебљивим напорима удружења и неразумевању од стране многих локалних сународника. Међутим, само читање библиотечких књига слабо је заступљено у записима. Првих година недостају практично сви подаци из библиотеке - број наслова, број читалаца и број позајмљених књига. Први траг оцене читалачке ситуације датира од 1 . марта 1925. године, а реч је о запису који се односи на 1924. годину: „, Могло би бити много више читалаца. Али у просеку се осећа напредак [...]. Најрадије читају историјске романе. “.

У суштини, читалаштво није било приоритет удружења током целог његовог постојања (подсећам на назив Чешка народна библиотека и читаоница). Напори за оснивање чешке школе постепено долазе до изражаја (први пут се помиње 3. јула 1927.), што ће се и остварити у школској 1928/1929. Иначе, удруживање је у пракси било другачије природе. Назив „библиотека и читаоница“ постало је пуко име удружења, које је увежбавало позоришне представе и имало свој оркестар и вођу оркестра, организовало редовне музичке приредбе укратко, није изненађујуће што се удружење 1933. године преименовало из Чешке народне библиотеке и читаонице у Чехословачку беседу.

Анализирајући каталог књига, дошао сам до закључка да су прве године у библиотеци биле само 23 чешке књиге. Од 1923. (или касније - тачан датум није наведен у изворима), Чешка библиотека и читаоница је добила 237 наслова на поклон од Министарства школства и народне просвете (чеш. MŠANO). Од овог тренутка књиге су у разврстане у каталогу по абецедном реду (претпостављам се да се радило о једнократном поклону). Година 1923. такође указује на године издања ових књига - све су морале бити издате 1923. или раније... Удружење је такође имало наслове који су објављени само једанпут, 1923. Међутим, могуће 
је да је каталогизација већ једном постојала , а тек након што је број наслова премашио број 23 појавила се потреба да се они уносе абецедним редом. За анализу самог каталога књига важна је чињеница да су на избор наслова утицали донатори (посебно MŠANO). Гледајући списак наслова, међутим, мора се рећи да је ово био један врло одговоран избор.

Остали додаци збирци били су разних врста, углавном резултат преноса књига из колекција несталих библиотека чешких досељеника у другим градовима Југославије. На основу начина прибављања првих додатака збирци, не треба да нас чуди да је међу књигама најмање $33 \%$ примерака у првом издању (или је најмање $20 \%$ књига неко од каснијих издања). Од књижевних форми, проза доминира са $88 \%$, а преостале форме представљају највише $4 \%$. Од укупно 260 књига (све наслови на чешком), 74,6\% је било од чешких аутора, а 25\% преведено на чешки (за $0,4 \%$ није могуће утврдити језик извора). Јасна је била потреба за читањем на чешком језику, и овде се наглашава када се ради о чешким ауторима, али то није било услов или приоритет. Међу преведеним насловима чини се занимљивим да је $43 \%$ превода са словенских језика (пољски, руски и бугарски). Ако овај број додамо чешким оригиналима, језичак на ваги показује $85.4 \%$ у корист словенских књижевности.

Ова чињеница говори не толико о чешкој идеји колико о идеји свесловенске узајамности, која је углавном још увек жива и евидентна у читавом друштву у Србији. Може се рећи да намера да се заустави ,југославизација“ Чеха није остварена, бар не међу самим члановима удружења (деца која похађају чешку школу могла би да буду извесна нада). Поређење два записа из 1930-их може бити доказ за то. 9. октобра 1934. године у Мерсеју је извршен атентат на краља Александра I Карађорђевића. Један запис приказује овај догађај на три странице текста. Ово оплакивање тешко се уопште може упоредити са написом у пет редова о смрти председника Томаша Гаригуа Масарика 1937. године. Тако су чешки сународници у Белој Цркви прво објавили нестајање чештва, које су желели да поново оживе на основу образовања „у чешком духу“. Читалаштво су намеравали да користе као средство образовања и удружење су назвали Чешка народна библиотека и читаоница. Пета генерација Чеха, која је прошла германизацију и мађаризацију, сусрела се логично са посрбљавањем након Првог светског рата. Међутим, чешки лингвоцентризам није био довољан за реконструкцију чештва и одржавање чешког језика. Нарочито када радни обим библиотечких услуга није испунио очекивања. Чешке књиге остају у Белој Цркви и чини се да ће (барем за читаоце) остати неоткривене.

Кључне речи: књиге, библиотека, читање, Југославија, Бела Црква, национални идентитет. 